\title{
Techniques Used in Forensic Psychological Examinations in Cases of Child and Adolescent Sexual Abuse ${ }^{1}$
}

\author{
Lara Lages Gava ${ }^{2}$ \\ Débora Dalbosco Dell'Aglio \\ Universidade Federal do Rio Grande do Sul, Porto Alegre-RS, Brazil
}

\begin{abstract}
Currently, there is no standardized protocol for the evaluation of situations of sexual abuse. Thus, this study investigated the techniques used by psychologists in forensic examinations in cases of suspected child and adolescent sexual abuse in the context of the criminal investigation. Semi-structured interviews, which were qualitatively analyzed using the WebQDA software, were applied with twelve psychologists who work as expert witnesses in the Medical-Legal Institute of six Brazilian capitals. The results showed a diversity of actions taken in the forensic examination practice, as well as consensus and controversy regarding the use of psychological testing and the credibility assessment of the report. Flexibility in conducting the forensic examinations by the teams was also observed, with the techniques used adapted according to the needs. The importance of the diversity of techniques was highlighted, as these aim to assist the expert witness to come to reliable conclusions, as well as maintain the rigor and technical quality of the evaluation.
\end{abstract}

Keywords: forensic psychological examination, sexual abuse, psychologist performance

\section{Técnicas Utilizadas nas Perícias Psicológicas em Casos de Abuso Sexual Infanto-Juvenil}

\begin{abstract}
Resumo: Atualmente, não há um protocolo padronizado para avaliação de situações de abuso sexual. Neste sentido, este estudo investigou as técnicas utilizadas por psicólogos na prática pericial em casos de suspeita de abuso sexual infanto-juvenil no contexto da investigação criminal. Doze psicólogos que atuam como peritos nos Institutos Médico-Legais de seis capitais brasileiras foram entrevistados com entrevistas semi-estruturadas, que foram analisadas qualitativamente com o auxílio do software WebQDA. Os resultados apresentaram uma diversidade de ações empreendidas na prática pericial, assim como a presença de consensos e controvérsias em relação ao uso de testes psicológicos e da avaliação da credibilidade do relato. Também foi observada flexibilidade por parte das equipes na condução das perícias, adaptando as técnicas de acordo com as necessidades. Destaca-se a importância da diversidade técnica, que visa a auxiliar o perito na busca de conclusões confiáveis, bem como a manter o rigor técnico e a qualidade das avaliações.
\end{abstract}

Palavras-chave: perícia psicológica judicial, abuso sexual, atuação do psicólogo

\section{Técnicas Utilizadas en las Pericias Psicológicas en Casos de Abuso Sexual Infanto-Juvenil}

\begin{abstract}
Resumen: Actualmente, no hay un protocolo estandarizado para evaluación de situaciones de abuso sexual. En este sentido, este estudio investigó las técnicas utilizadas por psicólogos en la práctica pericial en casos de sospecha de abuso sexual infantojuvenil en el contexto de la investigación criminal. Fueron utilizadas entrevistas semi-estructuradas con doce psicólogos que actúan como peritos en los Institutos Médico-Legales de seis capitales brasileñas, que fueron analizadas cualitativamente con el auxilio del software WebQDA. Los resultados presentaron una diversidad de acciones emprendidas en la práctica pericial, así como la presencia de consensos y controversias en relación al uso de pruebas psicológicas y evaluación de la credibilidad del relato. También fue observada flexibilidad por parte de los equipos en la conducción de las pericias, adaptando las técnicas de acuerdo con las necesidades. Se destaca la importancia de la diversidad técnica, que visa a auxiliar el perito en la búsqueda de conclusiones confiables, así como a mantener el rigor técnico y la calidad de las evaluaciones.
\end{abstract}

Palabras clave: pericia psicológica judicial, abuso sexual, actuación del psicólogo

The World Health Organization defines child sexual violence as any interaction between the child or adolescent and someone in a later stage of sexual development, the

\footnotetext{
${ }^{1}$ Paper derived from the doctoral dissertation of the first author, under the supervision of the second author, defended in the Programa de Pósgraduação em Psicologia of the Universidade Federal do Rio Grande do Sul, in 2012. Support: National Council for Scientific and Technological Development (CNPq).

2 Correspondence address:

Lara Lages Gava. Instituto de Psicologia. Universidade Federal do Rio Grande do Sul. Rua Ramiro Barcelos, 2600, Santa Cecília. CEP 91501-

970. Porto Alegre-RS, Brazil. E-mail: laralagesgava@gmail.com
}

motive of which is sexual satisfaction for the latter. It is exercised through erotic and sexual practices imposed using physical violence, threats, or inducement (World Health Organization, 2006).

The majority of sexual crimes against children and adolescents are not witnessed by others (Rivera T \& Olea, 2007; Rovinski, 2007) and rarely leave physical marks subject to investigation in a proof of evidence examination (Echeburúa \& Subijana, 2008; Welter \& Feix, 2010). Considering these aspects, in the context of the criminal investigation, there have been increasing requests for 
forensic examinations performed by professionals of the Psychology area.

The forensic psychological examination aims to clarify a fact of interest for the Judiciary, using to this end a set of Psychological theoretical and technical references (Rovinski, 2007; Schaefer, Rosseto, \& Kristensen, 2012). Resolution 008/2010 of the Federal Council of Psychology (Conselho Federal de Psicologia [CFP], 2010) specifically mentions the practice of the psychologist as an expert witness, as well as the relationship with the technical assistant, and points out that the forensic examinations performed by the psychologist may include the following techniques: observations, interviews, home and institutional visits, the application of psychological tests, the use of ludic resources and other instruments, as well as methods and techniques recognized by this council (CFP, 2010).

In cases of child and adolescent sexual abuse, criminal investigations can be considered a challenge for the expert witnesses and mental health professionals that assist the judicial authorities (Finnilä-Tuohimaa, Santtila, Sainio, Niemi, \& Sandnabba, 2009), as there is no a specific indicator that can be used to determine whether the child was abused or not. Therefore, to trust comprehensive evaluations more than specific indicators is recommended (Finnilä-Tuohimaa et al., 2009). These comprehensive evaluations, due to their qualitative nature, take different forms. Although there is agreement regarding the need to conduct the interview with the child, there is no consensus on the use of some of the techniques during the interview, such as the psychological tests or the credibility assessment of the account given by the child (Machado, 2005).

The disagreement in the use of psychological tests is due to the fact that none of them are able to identify a case of abuse (Machado, 2005). Thus, the procedure of the expert witnesses who use the tests consists of comparing the personality profile or symptoms with the framework commonly found in children and adolescents victims (Corwin \& Keeshin, 2011) inferring, from the compatibility of this comparison, the plausibility of the occurrence of the abuse (Machado, 2005). However, this can seem unreasonable, considering that there is no single symptomatology of abuse victims (Rivera T \& Olea, 2007) or that the victim may not present any apparent psychic consequence (Welter \& Feix, 2010).

The credibility assessment of the account given by the victim is also not a point of consensus. The best known protocol for the assessment of the veracity of the abuse claim is the Statement Validity Analysis - SVA (Vrij, 2005), a comprehensive global method to evaluate the credibility of the allegations of sexual abuse (Steller \& Boychuk, 1992). This technique is an adaptation of a procedure for analyzing the credibility of statements and has been used since the 1950s in the German courts to deal with situations where the only evidence was the uncorroborated testimony of the child victim (Machado, 2005). Some authors, however, are skeptical about the use of the SVA in the judicial context, explaining that the technique is not safe and has not been properly validated to be used as evidence (Brigham, 1999; Davies, 2001).

Considering that there are a number of elements without consensus regarding the evaluation in suspected child sexual abuse cases, as well as the concept that such evaluation basically has a qualitative nature, it can be understood why there is not a gold standard in the evaluation of abuse (Herman, 2005) and why Psychology is not close to presenting common guidelines on the subject (CFP, 2009). Given the diversity of actions in the forensic psychological examination practice in cases of sexual abuse, the present study sought to identify, in the context of the criminal investigation in the MedicalLegal Institutes (MLIs) of Brazil, techniques and actions being employed by psychologist expert witnesses in cases of suspected child and adolescent sexual abuse.

This study used a collective case study qualitative methodology (Stake, 2000), aimed at investigating the professional practice of psychologist expert witnesses in cases of suspected sexual abuse against children and adolescents. The specific aims were: (a) to verify the techniques used by psychologists from different regions of Brazil in the forensic examination practice in cases of suspected child and adolescent sexual abuse; (b) to determine the concept of the professionals regarding the use and purpose of the psychological tests; and (c) to evaluate the concept of the psychologists regarding the credibility assessment of the report.

\section{Method}

\section{Participants}

Participants were twelve psychologists who practiced as expert witnesses in the Medical-Legal Institutes of following state capital cities: Natal, Palmas, Brasília, Goiânia, Florianópolis and Porto Alegre. Among the respondents, only two were male. Regarding additional training, five were specialists in Forensic Psychology and one had a Postgraduate degree in Forensic Sciences.

\section{Instrument}

A semi-structured interview was used, with the aim of investigating the perceptions of the participants regarding: (a) the techniques used by the professionals in performing the forensic examination; (b) the use and purpose of psychological tests in this context; and (c) the credibility assessment of the report of the alleged victims.

\section{Procedure}

Data collection. Primarily, the Medical Legal Institutes of the capitals of all Brazilian states and the Federal District were contacted via telephone or email, in order to verify the locations in which the MLIs had psychologists acting as expert witnesses in cases of suspected child and adolescent sexual abuse. Among the 27 sites contacted, this forensic psychological examination activity was performed in the 
MLIs of only six capitals: Porto Alegre and Florianópolis in the south, Brasília and Goiânia in the central-west region, Palmas in the northern region, and Natal in the northeast.

Secondly, a researcher went to each of these locations to conduct semi-structured interviews with the expert witnesses who were part of these MLI teams. Up to three psychologists per team were interviewed, according to the availability of the participants. The interviews were carried out with the team members together, with an average duration of one and a half hours, and were recorded and transcribed.

Data analysis. The data were qualitatively analyzed with the aid of WebQDA, a software program for the analysis of qualitative data in a distributed collaborative environment (Souza, Costa, \& Moreira, 2011), allowing the analysis to be carried out by the different authors of this study, thereby increasing the reliability of the data obtained. It should be noted that the WebQDA software does not bias the analysis and leaves the researchers with full and flexible control of the material analyzed. This software allows the processing of data similar to the basic structure of Bardin's content analysis (2004), namely: (a) pre-analysis, with the organization of the material to be investigated; (b) exploration of the material, with coding (treatment of the material to achieve a better representation of its content) and categorization (simplified representation of the data); and (c) processing of the results, culminating in inferential interpretations. One difference presented by WebQDA in relation to the proposal of Bardin (2004) is that in the software the coding and categorization are performed simultaneously (Souza et al., 2011).

\section{Ethical Considerations}

All ethical procedures were followed in the performance of this study. The study was approved by the Research Ethics Committee of the Instituto de Psicologia of the Universidade Federal do Rio Grande do Sul, under protocol No. 2010063. The participants signed the Terms of Free Prior Informed Consent, agreeing to participate in the study.

\section{Results and Discussion}

Table 1 presents the denomination of the team of psychologists within each MLI, the number of psychologists who compose the team, and the length of time operating the forensic psychological examination in cases of suspected sexual abuse committed against children and adolescents. From the data two principle decades can be observed for the development, within the MLIs, of the service of forensic psychological examinations in cases of suspected child and adolescent sexual abuse. While the teams of Natal, Brasilia and Florianópolis started the service in the 1980s, the teams of Palmas, Goiânia and Porto Alegre began it in the 2000s. The team of Brasilia, although starting in 1982, said at the time the request for evaluation of child victims only occurred rarely, with the demand increasing considerably after the establishment of the Bureau for the Protection of Children and Adolescents (Delegacia de Proteção à Criança e ao Adolescente DPCA), in 1999.

It should be noted that, in the presentation of the results, the teams are randomly numbered, avoiding the identification of the participants for ethical reasons.

\section{Techniques Used by the Professionals}

For the performance of the forensic psychological examination in cases of suspected sexual abuse, all the teams reported conducting interviews with the child or adolescent victim and with their parents/guardian. Prior to the performance of these interviews, however, all the teams stressed the importance of reading and analyzing documents originating from the investigation, which is strongly indicated by the literature (Rivera T \& Olea, 2007; Serafim \& Saffi, 2012).

Regarding the interview with the parents/guardian, the teams reported that the goals are to seek overall information about the development of the child or adolescent through a brief history and to know whether he/she presents, or presented, psychological alterations possibly related to the abuse, in order to obtain data for the establishment of the causal link between the event and the resulting damage, if this was the case. All the teams reported that the interview with the parents/guardian is also used to obtain their version of the history of the facts, in order to compare this with the information obtained in the interview with the child or adolescent, as well as in the documents analyzed prior to the forensic examination. Team 1 stated that, through this interview, they also seek information related to the revelation of the abuse by the child and, in addition, aim to acquire knowledge about which steps were taken by the parents/guardian in relation to the behavioral and emotional alterations presented by the alleged victim.

Regarding the interview with the child or adolescent, teams 1, 4 and 6 stressed the importance of initiating a rapport phase, i.e., a phase of welcome in which, depending on the age of the alleged victim, toys, drawings or a conversation about neutral topics, such as activities in school and relationships with family and peers, can be used. In a second moment of the interview, the issue of abuse is approached, however, only through open questions, which are also known as general or exploratory questions and require the free recall of the child (Pisa \& Stein, 2006), such as "what happened?" or "why did you come here today?". Team 2, despite not presenting uniformity in their interviews, which are carried out together with social workers, also reported using open questions. It is important to stress that this type of question differs from closed questions, which are questions that require a yes/ no answer (e.g., "did he ask you to lie on the couch?"), and from forced choices, in which the child chooses one of the responses provided (e.g., "were you in your bedroom, in the living room, or in your parents' bedroom?"). The literature indicates that it is preferable to use open questions 
Table 1

Data of the Places of Data Collection

\begin{tabular}{lcccc}
\hline Location & Denomination of the Team & No. of Psychologists & Length of Time Operating & No. of Participants \\
\hline Natal & Forensic Psychology Sector & 4 & Since 1987 & 3 \\
Palmas & Psychosocial Sector & 6 & Since 2004 & 2 \\
Brasília & Forensic Psychopathology Sector & 4 & Since 1982 & 2 \\
Goiânia & Forensic Psychopathology Section & 1 & Since 2004 & 1 \\
Florianópolis & Psychology Service of the Bodily Injury Sector & 2 & Since 1987 & 2 \\
Porto Alegre & Forensic Psychological Examinations Sector & 4 & Since 2009 & 2 \\
\hline
\end{tabular}

when carrying out interviews with children (Echeburúa \& Subijana, 2008; Pisa \& Stein, 2006).

After the open questions phase, team 6 said that they used closed questions only when necessary to clarify doubts or possible contradictions, ending the interview with a return to the neutral themes phase, as the alleged victim may have become emotionally destabilized when speaking about the abusive episode. Also in relation to the interview with the child or adolescent, teams 3 and 5 reported the use of the Cognitive Interview technique, which uses scientific knowledge about the memory in order to obtain more precise statements, and also favors the use of open rather than closed questions (Feix \& Pergher, 2010).

In the investigations of situations of child sexual abuse, when considering the absence of physical marks and other witnesses, the interview should be seen as the main instrument of the psychologist. The observation of symptoms, although they may be associated with a traumatic event, does not provide information about a concrete and specific situation. In the majority of cases, therefore, it is only the testimony of the child that can make the violence suffered visible and audible (Stein, Pergher, \& Feix, 2009).

During the performance of the interview, the teams reported using other techniques, depending on each case: psychological tests, drawings, dolls and other ludic activities, written report, the book cover technique, and clinical observation. Some teams also reported the use of SVA for the credibility assessment of the report. The results regarding the psychological tests, as well as those relating to SVA are reported in subsequent sections of this article.

In relation to the drawing, dolls, and other ludic activities, all the teams stressed that these techniques were not used in all the interviews, but that it depends on the age of the child, being primarily used with younger children, with the aim of welcoming them and establishing a bond. The literature indicates that ludic activities facilitate both the bond and the listening of the child (Froner \& Ramires, 2008). Specifically in relation to the dolls, and the function of rapport, team 3 reported also using them to facilitate the emission of the report of the alleged abusive situation. This team noted, however, that the dolls are only used when the alleged victim has already reported the abusive episode, however, had difficulties in providing details about the situation. In such cases the alleged victims could show what happened to them using the dolls.

Two techniques described by team 1 were prominent, namely, the written report and the book cover technique. Given the difficulty in speaking about the alleged abusive episode, either due to shame or fear, the expert witness can use the written report technique, which is simply to ask the alleged victim to write about what was experienced on a sheet of paper. With access to this written report, the expert can continue conversing about elements presented on the paper, thus obtaining further information regarding the situation supposedly experienced by the child or adolescent.

The strategy we call the book cover technique in this article, in turn, consists of a graphical technique that was created by one of the members of team 1 . The psychologist said that, faced with a very unclear case, she asked the alleged victim to make drawings about the report that she had. In the words of the psychologist, after the formulation of the report of the forensic examination, she said: "Let's do the following, you told me a story and we are going to make a book of this story. But I need a picture to put on the cover, because every book has a drawing on the cover $[\ldots]$. ." The psychologist went on to say:

Then she drew the whole scene in which she was abused, there was a television, she was sleeping in a hammock in the living room, she drew all the elements. $[\ldots .$.$] Then we started to use it more often and it always$ works. It always works. Sometimes they even say: 'Ah, I won't draw it, no', and when you look again they are already drawing the whole scene! And the drawing helps because either it omits some details, or adds details. And then you start telling the story too, to see to what extent there are contradictions, what is and what is not, you know? It helps!

On several occasions throughout the interview, team 4 mentioned the role of clinical observation in the forensic examination. One team member reported:

Clinical observation is also very important for us to see how the child behaves, even during the report. For example, a child who speaks, speaks, speaks... speaks a lot and that talks about everything, but at 
the time of reporting the violence does not speak, the child withdraws.

The team added that it is also feasible to use clinical observation of the child together with the mother and father, when their presence is possible, in order to verity the kind of relationship established between the parents/ guardian and the child, especially in cases where parental alienation is suspected.

Based on the data exposed, there is a diversity of actions employed in the forensic examination practice in different places. Despite the diversity, it can be concluded that the focus of the investigative evaluation in all the teams is on the alleged victim, so that the parents/guardian participate in the evaluation only in so much as they can assist with information about the child and the situation in question. The evaluation with the focus on the child is probably related to the fact that this is who can provide more reliable information about the alleged abuse, since the crime is generally committed without witnesses (Rovinski, 2007).

\section{Use and Purpose of the Psychological Tests}

All the teams reported using psychological tests in the forensic examination in cases of suspected sexual abuse committed against children and adolescents. However, while teams 1, 3 and 6 used psychological tests only in specific situations, teams 4 and 5 used the tests in almost all interviews performed. In relation to team 2 , there was no consensus regarding the use of the tests.

Team 1 said that they used the tests in order to confirm what they already suspected from the clinical evaluation, in order to provide more objective information for the report. For example, faced with unclear indications of stress and/or depression, stress and/or depression scales are used, faced with indications of cognitive impairment or upon request from the judicial authority, intelligence tests are used, such as the Columbia Mental Maturity Scale or the WISC-III subtests. The choice of the use of only subtests was due to the fact of that the WISC-III is a lengthy test for application in the forensic examination context.

Team 1 also reported use of the House-Tree-Person (HTP) test, however, with the primary function of assisting in the interaction with the child, because, although this test provides evidence of anxiety, tension, insecurity and other aspects typically present in cases of sexual abuse, it would not be possible to state that such feelings arose specifically from the abusive situation allegedly experienced. This team explained that when a child is referred for the forensic examination, he/she can experience these feelings (stress, anxiety, insecurity) for other reasons, such as the very fact of being back in the MLI, where they had already been to perform the physical examination for the crime report, which is an invasive procedure. In fact, the occurrence of sexual abuse can not be concluded based on the identification of symptoms when performing a forensic examination, as these, when present, are non-specific, i.e., they may also be due to situation other than sexual abuse (Dammeyer, 1998). It can, therefore, be perceived that team 1 uses the tests with caution, critically positioning itself in relation to its purposes: "[...] to what extent does the test will really show the anxiety of the person, $[\ldots]$ is the stress one that has been experienced for a long time, or only of the moment of the evaluation and not of the abuse?" Finally, team 1 said that the use of the tests is not rigid or obligatory, clarifying that they do not possess an evaluation standard, so that a choice of one or other instrument depends on the specifics of each case.

Team 3 also said that they only used tests on specific occasions. Depending on the age, they said they worked with the Rorschach and the HTP tests, in order to observe data regarding personality and emotional traits, verifying whether the emotional state of the alleged victim presented in the tests corroborates that observed clinically. As with team 1, team 3 said that the use of the tests has the aim of confirming what has been clinically observed by the psychologist. The team also stressed that the MLI does not have the tests, so that its members need to use their own material to perform the forensic examinations.

Team 6 said that they do not normally use psychological tests during the evaluations. The tests are only used in cases in which the results could assist in the report, as stated below:

We only use them if we think it is necessary. For example, it may be very important that I say, or at least it will help in my argument if I say, that the child has a severe cognitive impairment, you know? Because, this is a limitation that could prevent the child from defending himself.

In these cases, the team said that they made use of the WISC-III, however such use is currently being questioned:

To perform a complete WISC test to say that the IQ is $\mathrm{X}$, to say that the child has retardation, when in fact the retardation is clinically visible [...] So I have even asked myself about the amount of work that this is, even for the child.

The team also said that in a few situations they use projective tests, however, only in order to better understand the child, i.e., to understand the child's difficulties and how these are included in their history, and not in order to define the presence or absence of the abuse.

For team 4, the tests are essential, being used in virtually all forensic examinations, as they seek to carry out a psychodiagnosis of the alleged victims. Nevertheless, there is no general standard of evaluation, so that only after an overview of the case, obtained through the interview, is the battery of tests appropriate to the case chosen. Team 4 also used intelligence tests, the choice of which depends on the age and education of the child. Although this team emphasized 
that the main aim of the forensic examination is not to obtain the story from the child, but his/her psychodiagnosis, they said that the results of this can be highlighted as being related to a possible problem or trauma experience.

Teams 5 and 4, used the tests in almost all interviews, in order to materialize the contents of the interview. Projective techniques were used, especially the Rorschach and HTP tests, as, according to the team, these tests can provide responses that are compatible or consistent with responses from people who have gone through abusive situations. The team also reported that they use intelligence tests when there is a requirement from the legal authority or when the clinical evaluation is not sufficient to assess possible cognitive impairment of the alleged victim.

Team 5 also said that the tests help their report to become more reliable due to a cultural issue of the region, overall regarding the use of the Rorschach, which is considered by the authorities as legal proof of the occurrence of abuse. It should be noted, however, that the legal authorities can not and should not decide which test the psychologist should use, with the choice of the techniques to be used in the evaluation being solely and exclusively for the psychology professional. Team 5 positioned themselves in relation to the use of the Rorschach and the misconception that this would be proof of the occurrence of abuse:

This test is not an x-ray, it is not the same as the laboratory examination: is the virus present or not? We work with perceptions, with experiences, projections. And we cannot give 100\% reliability in what we are investigating [...]. So, I think the view they have of the tests here is slightly distorted.

The team spoke critically in relation to this distorted concept, believing there are other ways to perform the forensic examinations without necessarily working with tests.

The requirement for using tests by legal authorities seems to be related to a certain mythology about the tests, i.e., the notion that they allow hidden truths to be touched (Brodzinsky, 1993), with these authorities having an unrealistic view of what a psychological test may or may achieve. Without having knowledge about the possibilities of the tests, lawyers, prosecutors and judges ultimately consider that the use of tests itself provides a special science to the evaluation process, which is an erroneous view (Machado, 2005).

In relation to team 2, while a part of the team reported always using the HTP test (when the child's age allowed), others said that they did not use tests. Those using the HTP said that this is not always helpful in the performance of the forensic examination, however, it can be so, especially on occasions when it is possible to identify family conflicts. Thus, the data obtained from the application of the HTP could be compared with those obtained in the interview with the parents/guardian, allowing, in some cases, the identification of controversies between the report of the parents/guardian and the family situation actually experienced. The another part of the team said they did not use tests because the main aim of the forensic examination is to evaluate the situation of abuse, however, the tests are not capable of identifying these situations, giving preference, therefore, to the discourse of the alleged victim.

It should be emphasized that the battery of tests used by each team was not limited to the tests cited. Considering that this is a qualitative work resulting from a single interview with each team, it is possible that the participants used other tests that were not listed here. However, the main aim was to investigate how the tests were being used in the performance of the forensic examination. The description of the results supports the concept that, although there is a consensus on the technical specificity required for the evaluation of abuse, in the evaluations there is frequent recourse to wide spectrum psychological evaluation instruments, such as the Rorschach or WISC (Machado, 2005). In Brazil, as in other places, we found instruments formulated for the clinical area being used in forensic evaluations (Archer, Buffington-Vollum, Stredny, \& Handel, 2006; Waterman \& Lusk, 1993), which is probably due to the absence of specific instruments for forensic evaluation in the Brazilian context.

Although the psychological test is an instrument for the exclusive use of the psychologist, the expert witness must be aware of its limitations, since no psychometric or projective instrument can determine whether a child, adolescent or adult was or was not a victim of aggression (Casoni, 2001) or, more specifically, of sexual abuse. Since the tests do not provide direct indicators regarding the abuse, the use of these instruments by the teams interviewed in this study consisted of, as pointed out in the literature (Corwin \& Keeshin, 2011; Machado, 2005), the comparison of the personality profile or symptomatology presented by the child with the framework typically found in victims of abuse, inferring, from the compatibility of the profiles, the possibility that an abusive experience occurred. However, given the lack of a unique profile of the victims, the need is highlighted for the interpretation of the test results, taking into consideration an evaluation that integrates multiple methods and various sources of information, with the battery of tests not being the only source of information (Quinnel \& Bow, 2001).

\section{Credibility Assessment of the Report of the Alleged Victims}

All teams considered it important to assess the credibility of the report of the alleged victims, except for team 4, which is probably related to the purpose of the forensic examination in each location. While all the teams reported mainly focusing on the report of the alleged victim, team 4 said that they perform an forensic examination directed toward the diagnostic situation of the person examined, so that "the goal is not specifically the report, but a diagnosis set in which the report is a part, but not the most important." Among the teams that consider it important to carry out the credibility assessment, team 6 reported that they made use of the Statement Validity Assessment. In teams 3 and 1, while 
some mentioned the use of the SVA, some said that they did not use it due to lack of access or knowledge concerning the technique. Team 2 also said that they did not use the SVA due to lack knowledge about the technique.

The SVA currently consists of five steps, namely: (a) careful review of the information available in relation to the case; (b) structured interview; (c) Criteria-Based Content Analysis - (CBCA), in which the content and the quality of the data obtained from the presence or absence of 19 objective criteria are assessed in a systematic way; (d) validity checklist, in which the results of the CBCA are evaluated from a validity control list for the criteria surveyed; and (e) integration of all the data gathered for the development of the conclusion, in probabilistic terms, regarding the occurrence of abuse (Steller \& Boychuk, 1992).

Team 6 said that despite using the SVA, the members currently questioned its actual validity. Among the difficulties in relation to the use of the SVA, the team pointed out that sometimes there had been reports almost without criterion of credibility in which a probability of abuse could be concluded, while on the other hand, there had been reports that had a number of criteria of credibility, however, a probability of abuse could not be concluded. Furthermore, the team highlighted that the method cannot be used with preschool children and that it does not allow them to differentiate between whether a story is true or false. All these difficulties encountered in practice have been previously highlighted in the literature (Juárez López, 2004). Steller, one of the creators of the SVA, recognized the difficulties related to the use of this method and proposed that this should not be considered as proof of the general validity of the credibility test, but as a global method for assessing the credibility of declarations (Steller \& Boychuk, 1992).

The members of teams 3 and 1, who did not use the SVA, as well as teams 5 and 2, said that they intuitively conducted a credibility evaluation, based on aspects the literature highlights in cases of sexual abuse. For example, this could be identified in the report of team 5 when they mentioned the child's use of knowledge inappropriate for his/her age group:

One thing is the child saying: 'he touched my peepee, touched my bottom, touched my fanny [...]'; another thing is the child saying: 'He touched my penis, touched my vagina, touched my anus'. It's different, it is more formalized knowledge. If it is a case of simulation, the parents do not usually have this $[\ldots]$ guile to give information the way the child understands. Usually they give information in a way that they would give it, or that the school gives it.

In addition to knowledge inappropriate for the age group, the teams also mentioned as indicators of credibility, the absence of contradictions in the report of the child, coherence between the report and affection shown, and the presence of threat content, typically found in cases of child sexual abuse (Furniss, 1993).
Finally it should be noted that all of these indicators are also present in the SVA itself. However, abstinence on behalf of the professionals regarding the use of the SVA, given the lack of knowledge about this method, highlights the caution the teams employed in relation to techniques that they use. Such abstinence can be considered an ethical position, especially when it is considered that the SVA is a controversial technique that involves a tendency for false claims to be considered true (Juárez López, 2004).

\section{Final Considerations}

Throughout this study, we sought to investigate the techniques and actions employed by psychologist expert witnesses in the evaluations in cases of suspected child and adolescent sexual abuse in the forensic context. It was found that in all the teams, despite the different techniques used, the focus of the investigative evaluation was on the alleged victim. While team 4 proposed that the aim of the forensic examination is to draft the psychodiagnosis of the alleged victim, the other teams, without neglecting an evaluation of the symptoms, understood the priority to be to obtain the report of the facts about the abuse. Among the techniques, the relevance of the interview was highlighted, due to its ability to make the solid facts of the violence clear. This technique, however, requires staff training, covering the technique and theory, as well as interpersonal skills and experience, so that it can be well used by the professional (Faller, 2007; Machado, 2005). The psychological tests, while not presenting direct indicators of abuse, have been used as an aid in the comparison of the personality profile or symptomatology displayed by the child with the framework typically found in victims of abuse. The credibility assessment, in turn, was performed both intuitively and through the SVA, depending on the location, with the SVA being questioned in relation to its validity.

From this study, it was also observed that the participants had carried out the forensic examination assessment using diverse methods (interviews, tests, credibility assessment) and information sources (documents from the investigation or judicial proceedings, the alleged child victim and the parents/ guardian). However, in some situations it was found that the delimitation of the methods used is driven by the previous knowledge of the professionals rather than by a technical decision, or by the influence of the judicial authorities, who sometimes ask for certain tests. It can also be observed, cases in which the lack of material, e.g., the availability of the tests, prevents their use, causing the professional to resort to other available techniques or even to create new techniques. Despite these aspects, such diversity seems to be positive and contribute to ensuring the technical accuracy and quality of the assessments because, since there is not a specific indicator of the occurrence of abuse, the more devices the expert witness can use to confirm or exclude the hypotheses developed about each case, the more consistent will be the proof (Echeburúa \& Subijana, 2008). This consistency is fundamental and ensures what is called the "social value of the role of the expert witness" (Machado, 
2005), since in many instances the surveys are not acted upon or the perpetrator is acquitted due to lack of robustness in the documentation of the offense, frustrating the expectations of the victims and their families in relation to the Justice system (Santos, 2011). In addition, the flexibility presented by the psychologists interviewed, who demonstrated varying their techniques depending on the case and the age of the child or adolescent, can also be considered positively, as it contributes to the performance of a more appropriate evaluation.

Thus, from the results of this study, it can be concluded that the practical work of psychologists in forensic psychological examinations is still a challenge, because, although a body of technical knowledge in the area can be observed, there are still many aspects that need to be further investigated and developed. We emphasize the need to continue the debate regarding the use and purpose of psychological tests, and about the validity of the methods for assessing the credibility of the report. It is suggested, therefore, that national studies are performed to construct and validate psychological evaluation instruments in the forensic area context, contributing to the instrumentalization of the professionals working in this still incipient field. It should be noted that the number of psychologist expert witnesses in Brazil is still very small, and its practice very recent, considering that half of the MLIs that have psychologists who perform forensic examinations in sexual abuse cases have emerge within the previous 10 years, however, it seems to be a growing area. The need should be highlighted for national studies that aim to investigate the efficacy of the SVA, considering that its use has not been evaluated in any area of psychological investigation in Brazil. Even internationally, there is still controversy about its use and application, making it difficult for the professional to consistently choose this instrument. Thus, new investments in studies on techniques in the forensic examination area in cases of child and adolescent sexual abuse are needed in order to allow psychologists to provide the judicial authorities with increasingly consistent proof, assisting them in holding the offender responsible and in ensuring the integral protection of the children.

\section{References}

Archer, R. P., Buffington-Vollum, J. K., Stredny, R. V., \& Handel, R. W. (2006). A survey of psychological test use patterns among forensic psychologists. Journal of Personality Assessment, 87(1), 84-94. doi:10.1207/s15327752jpa8701_07

Bardin, L. (2004). Análise de conteúdo (3rd ed.). Lisboa: Edições 70.

Brigham, J. C. (1999). What is forensic psychology, anyway? Law and Human Behavior, 23(3), 273-298. doi:10.1023/A:1022304414537

Brodzinsky, D. M. (1993). On the use and misuse of psychological testing in child custody evaluations. Professional Psychology: Research and Practice, 24(2), 213-219. doi:10.1037/0735-7028.24.2.213

Casoni, D. (2001). Les trois étapes de l'évaluation des allégations d'agression sexuelle. Psychologie Québec, 18(5), 23-25.
Conselho Federal de Psicologia. (2009). Serviço de proteção social a crianças e adolescentes vítimas de violência, abuso e exploração sexual e suas famílias: Referências para a atuação do psicólogo. Brasília, DF: Conselho Federal de Psicologia.

Conselho Federal de Psicologia. (2010). Resolução No. 008. Dispõe sobre a atuação do psicólogo como perito e assistente técnico no Poder Judiciário. Retrieved from http://site.cfp. org.br/wp-content/uploads/2010/07/resolucao2010_008.pdf

Corwin, D. L., \& Keeshin, B. R. (2011). Estimating present and future damages following child maltreatment. Child and Adolescent Psychiatric Clinics of North America, 20(3), 505-518. doi:10.1016/j.chc.2011.03.005

Dammeyer, M. D. (1998). The assessment of child sexual abuse allegations: Using research to guide clinical decision making. Behavioral Sciences \& the Law, 16(1), 21-34. doi:10.1002/(SICI)1099-0798(199824)16:1<21::AIDBSL291>3.0.CO;2-K

Davies, G. M. (2001). Is it possible to discriminate true from false memories? In G. M. Davies, \& T. Dalgleish (Eds.), Recovered memories: Seeking the middle ground (pp. 153176). Chichester, England: Wiley.

Echeburúa, E., \& Subijana, I. J. (2008). Guía de buena práctica psicológica en el tratamiento judicial de los niños abusados sexualmente. International Journal of Clinical and Health Psychology, 8(3), 733-749.

Faller, K. C. (2007). Interviewing children about sexual abuse: Controversies and best practices. New York, NY: Oxford University Press.

Feix, L. F., \& Pergher, G. K. (2010). Memória em julgamento: Técnicas de entrevista para minimizar as falsas memórias. In L. M. Stein, Falsas memórias: Fundamentos cientificos e suas aplicações clínicas e jurídicas (pp. 209-227). Porto Alegre, RS: Artmed.

Finnilä-Tuohimaa, K., Santtila, P., Sainio, M., Niemi, P., \& Sandnabba, K. (2009). Expert judgment in cases of alleged child sexual abuse: Clinicians' sensitivity to suggestive influences, pre-existing beliefs and base rate estimates. Scandinavian Journal of Psychology, 50(2), 129-142. doi:10.1111/j.1467-9450.2008.00687.x

Froner, J. P., \& Ramires, V. R. R. (2008). Escuta de crianças vítimas de abuso sexual no âmbito jurídico: Uma revisão crítica da literatura. Paidéia (Ribeirão Preto), 18(40), 267-278. doi:10.1590/S0103-863X2008000200005

Furniss, T. (1993). Abuso sexual da criança: Uma abordagem multidisciplinar, manejo, terapia e intervenção legal. Porto Alegre, RS: Artes Médicas.

Herman, S. (2005). Improving decision making in forensic child sexual abuse evaluations. Law and Human Behavior, 29(1), 87-120. doi:10.1007/s10979-005-1400-8

Juárez López, J. R. (2004). La credibilidad del testimonio infantil ante supuestos de abuso sexual: Indicadores psicosociales (Unpublished doctoral dissertation). Universitat de Girona, Girona, España. 
Gava, L. L., \& Dell'Aglio, D. D. (2013). Forensic Psychological Examinations in Cases of Sexual Abuse.

Machado, C. (2005). Avaliação da credibilidade de alegações de abuso sexual: Consensos e controvérsias. Psicologia, Educação e Cultura, 9(2), 513-534.

Pisa, O., \& Stein, L. M. (2006). Entrevista forense de crianças: Técnicas de inquirição e qualidade do testemunho. Revista da Ajuris, 33(104), 217-255.

Quinnel, F. A., \& Bow, J. N. (2001). Psychological tests used in child custody evaluations. Behavioral Sciences \& the Law, 19(4), 491-501. doi:10.1002/bsl.452

Rivera T., J., \& Olea, C. (2007). Peritage en víctimas de abuso sexual infantil: Un acercamiento a la práctica chilena. Cuadernos de Neuropsicología, 1(3), 284-295.

Rovinski, S. R. (2007). Fundamentos da perícia psicológica forense. São Paulo, SP: Vetor.

Santos, S. S. (2011). Uma análise do contexto de revelação e notificação do abuso sexual: A percepção de mães $e$ de adolescentes vitimas (Unpublished doctoral dissertation). Universidade Federal do Rio Grande do Sul, Porto Alegre, RS.

Schaefer, L. S., Rossetto, S., \& Kristensen, C. H. (2012). Perícia psicológica no abuso sexual de crianças e adolescentes. Psicologia: Teoria e Pesquisa, 28(2), 227-234. doi:10.1590/S0102-37722012000200011

Serafim, A. P., \& Saffi, F. (2012). Psicologia investigativa nos casos de suspeita de abuso sexual. In B. M. Paulo (Org.), Psicologia na prática jurídica: A criança em foco (2nd ed., pp. 260-272). São Paulo, SP: Saraiva.

Souza, F. N., Costa, A. P., \& Moreira, A. (2011). Análise de dados qualitativos suportada pelo software webQDA. Actas da Conferência Internacional de TIC na Educação: Perspetivas de Inovação, 7, 49-56.

Stake, R. E. (2000). Case studies. In N. K. Denzin, \& Y. S Lincoln (Eds.), Handbook of qualitative research (2nd ed., pp. 435-454). Thousand Oaks, CA: Sage.

Stein, L. M., Pergher, G. K., \& Feix, L. F. (2009). Desafios da oitiva de crianças e adolescentes: Técnica de entrevista investigativa. Brasília, DF: SEDH/PR. Retrieved from http://media.wix.com/ugd/2dfb33 a1fc24141ce22d9331eb8677eb6424e4.pdf

Steller, M., \& Boychuk, T. (1992). Children as witnesses in sexual abuse cases: Investigative interview and assessment techniques. In H. Dent, \& R. Flin (Eds.), Children as witnesses (pp. 47-73). New York, NY: John Wiley \& Sons.

Vrij, A. (2005). Criteria-based content analysis: A qualitative review of the first 37 studies. Psychology, Public Policy, and Law, 11(1), 3-41. doi:10.1037/1076-8971.11.1.3

Waterman, J., \& Lusk, R. (1993). Psychological testing in evaluation of child sexual abuse. Child Abuse \& Neglect, 17(1), 145-159. doi:10.1016/0145-2134(93)90014-V

Welter, C. L. W., \& Feix, L. F. (2010). Falsas memórias, sugestionabilidade e testemunho infantil. In L. M. Stein, Falsas memórias: Fundamentos cientificos e suas aplicações clínicas e jurídicas (pp. 157-185). Porto Alegre, RS: Artmed.
World Health Organization. (2006). Preventing child maltreatment: A guide to taking action and generating evidence. Geneva, Switzerland: World Health Organization.

Lara Lages Gava is a Ph.D. in Psychology from Universidade Federal do Rio Grande do Sul and a Criminal Expert Witness of the Instituto Geral de Perícias do Rio Grande do Sul.

Deborah Dalbosco Dell'Aglio is an Associate Professor of the Instituto de Psicologia of the Universidade Federal do Rio Grande do Sul.

Received: Aug. $20^{\text {th }} 2012$

$1^{\text {st }}$ Revision: Aug. $7^{\text {th }} 2013$

Approved: Aug. $12^{\text {th }} 2013$
How to cite this article:

Gava, L. L., \& Dell'Aglio, D. D. (2013). Techniques used in psychological expertise in cases of sexual abuse in children and adolescents. Paidéia (Ribeirão Preto), 23(56), 359-367. doi:10.1590/1982-43272356201310 


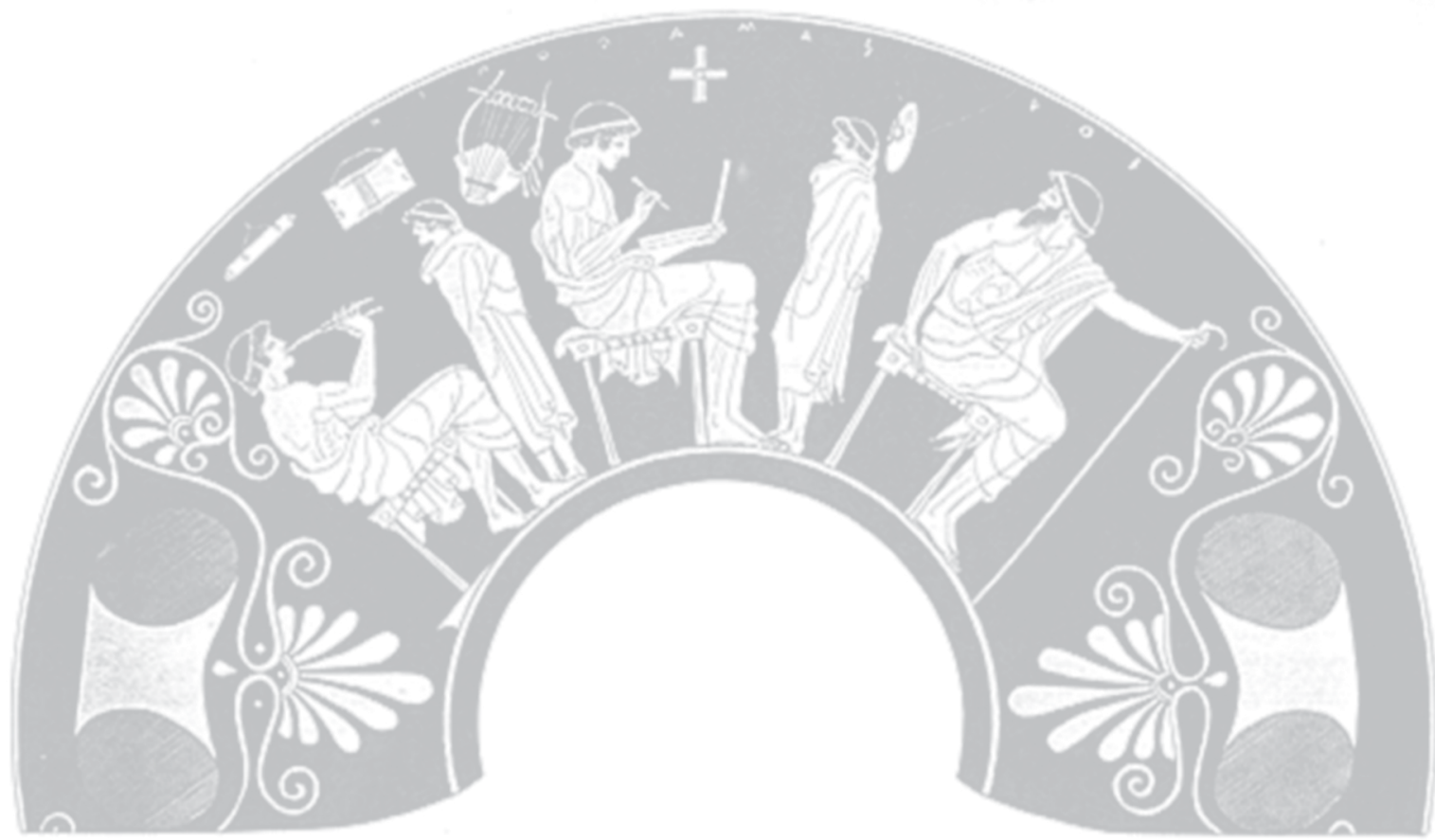

